\title{
Environmental concerns related to the construction of offshore wind parks: Baltic Sea case
}

\author{
L. Rostin, G. Martin \& K. Herkül \\ Estonian Marine Institute, University of Tartu, Estonia
}

\begin{abstract}
Wind energy is considered to be one of the most promising sources of renewable energy in the future. Planning and construction of offshore wind parks is very active in the Northern Europe and Baltic Sea area. Currently, numbers of largescale projects are under development in the Baltic Sea area and, in most cases, the information on proper environmental impact assessment (EIA) of this activity is missing. There are a number of environmental concerns that are well documented from terrestrial environment (e.g. effects on bird migration) but the marine environment creates some additional possible impacts and threats. Some of them are already well studied, but many aspects remain unclear. The Baltic Sea, being a unique ecosystem, is considered to be vulnerable to many pressures which can be caused by large construction activities. These harmful effects can be destruction and modification of habitat characteristics during the construction phase, noise pollution during construction and low frequency vibration during operation, modification of migration routes, formation of artificial substrate and favourable conditions for alien species invasion etc. Besides harmful impacts, also some positive effects on local biodiversity are usually mentioned, such as the so-called "reef effect".

In the current paper we analyse existing information on the known effects of the construction of offshore wind parks in the Baltic Sea area and illustrate the negative and positive effects of the construction activities on local biodiversity based on a study performed in the framework of EIA of offshore wind park development project in the north-eastern Baltic Sea (Neugrund bank, Gulf of Finland). Results are generalized for the whole Baltic Sea area and recommendations are drawn for EIA studies of future development projects.

Keywords: Baltic Sea, North Sea, offshore wind park, marine biota, marine ecosystem, reef effect, renewable energy.
\end{abstract}




\section{Introduction}

Currently and in the nearest future wind energy is going to be one of the key renewable energy sources. This is important resource, exploitation of which is increasing fast because of the general concern about global warming and limited oil resources in the world [1]. It is proved to be a reliable, natural and renewable source of electrical power supply $[1,2]$. This technology has potential to significantly reduce the emission of carbon dioxide and the use of fossil fuels and their negative impact on the environment. Emission of carbon dioxide takes place only during the construction, maintenance and decommissioning phases of operation of offshore wind parks while energy generation, at the operation phase, is carbon dioxide neutral [2].

Offshore marine environment, that is characterized by extensive resources of frees space and strong winds, provides an enormous supply of wind energy $[1,3]$. Large area allows to install large wind parks and higher wind speed permits installation of more efficient wind turbines. Installing the wind farm far from shore enables different designs of wind turbines and ensures more effective use of wind [1].

In the Baltic Sea and North Sea, there are currently number of operating (as shown in table 1), under construction and planned offshore wind farms. The majority of wind farms in the North Sea belong to United Kingdom and Denmark. In the Baltic Sea the largest wind farm, Nysted II, is installed in Danish coastal waters. There are also a number of single and test wind turbines in the area [4].

In the near future, there are plans for much larger number of offshore wind park construction projects. Large-scale wind farms are currently advancing in the United Kingdom, Denmark, Germany and Estonian marine areas [4].

\section{The Baltic Sea as a unique marine ecosystem}

The Baltic Sea is a unique marine ecosystem featured by presence of large variety of environmental gradients. Among those, most remarkable are NorthSouth and East-West salinity gradient, North-South climate related gradients of water temperature and ice conditions and East-West gradient of coastal habitats (changing from Scandinavian archipelago or skerry type coasts to exposed sandy beaches and limestone cliff coasts). All this contributes to several gradients in habitats and biodiversity as a whole. In addition to that there exist many different large-scale and local gradients in human impact by human introduced nutrient enrichment leading to eutrophication, pollution by toxic substances and oil products as well as mechanical disturbance by coastal defence and other construction.

On the whole Baltic Sea scale the biodiversity is most vulnerable in the central part - around the basin called Baltic Proper. According to checklist of macroscopic species published by HELCOM the lowest number of macroscopic species in the Baltic could be observed in basins around the central part (Baltic Proper, Gulf of Riga, Archipelago Sea) [5]. This corresponds to the sea area 
Table 1: Operating offshore wind farms in the Baltic and North Seas [4].

\begin{tabular}{|l|c|c|c|c|c|}
\hline & & & & \\
& & & & \\
& & & & \\
& & & & \\
\hline Greater Gabbard & United Kingdom & 2012 & North Sea & 140 & 504 \\
\hline Sheringham Shoal & United Kingdom & 2012 & North Sea & 88 & 316.8 \\
\hline Baltic I & Germany & 2011 & Baltic Sea & 21 & 48.3 \\
\hline Nysted II & Denmark & 2010 & Baltic Sea & 90 & 207 \\
\hline Gunfleet Sands I + II & United Kingdom & 2010 & North Sea & 48 & 172.8 \\
\hline Thanet & United Kingdom & 2010 & North Sea & 100 & 300 \\
\hline Alpha Ventrus & Germany & 2010 & North Sea & 6 & 60 \\
\hline Belwind Phase I & Belgium & 2010 & North Sea & 55 & 165 \\
\hline Horns Rev II & Denmark & 2009 & North Sea & 91 & 209 \\
\hline Lynn & United Kingdom & 2009 & North Sea & 27 & 97.2 \\
\hline Inner Dawsing & United Kingdom & 2009 & North Sea & 27 & 97.2 \\
\hline Thorontobank & Belgium & 2009 & North Sea & 6 & 30 \\
\hline Sprogø & Denmark & 2009 & Baltic Sea & 7 & 21 \\
\hline Princess Amalia & Netherlands & 2008 & North Sea & 60 & 120 \\
\hline Egmond an Zee & Netherlands & 2008 & North Sea & 36 & 108 \\
\hline Lillgrund & Sweden & 2008 & Baltic Sea & 48 & 110 \\
\hline Kemi Ajos I + II & Finland & 2008 & Baltic Sea & 10 & 30 \\
\hline Irene Worrink & Netherlands & 2006 & North Sea & 28 & 16.8 \\
\hline Kentish Flats & United Kingdom & 2005 & North Sea & 30 & 90 \\
\hline Scroby Sands & United Kingdom & 2004 & North Sea & 30 & 60 \\
\hline Nysted I & Denmark & 2003 & Baltic Sea & 72 & 165.6 \\
\hline Samsø & Denmark & 2003 & Baltic Sea & 10 & 23 \\
\hline Rønland & Denmark & 2003 & North Sea & 8 & 17.2 \\
\hline Horns Rev I & Denmark & 2002 & North Sea & 80 & 160 \\
\hline Yttre Stengrund & Sweden & 2001 & Baltic Sea & 5 & 10 \\
\hline Middlegrund & Denmark & 2000 & Baltic Sea & 20 & 40 \\
\hline Utgrunden I & Sweden & 2000 & Baltic Sea & 7 & 11 \\
\hline Bockstigen & Sweden & 1998 & Baltic Sea & 5 & 2.75 \\
\hline Tuno Knob & Denmark & 1995 & Baltic Sea & 10 & 5 \\
\hline Vincleby & Denmark & 1991 & Baltic Sea & 11 & 4.95 \\
\hline
\end{tabular}

where the salinity gradient is most unfavourable both for marine and brackish water species. At the same time this area is most favourable for development of wind parks having the best properties of wind climate. Analyses made on the data obtained from habitat modelling performed by EU funded BALANCE project show that the depth interval suitable for wind park development overlaps with most of the habitat diversity and existing nature conservation activities in the area. Almost $75 \%$ of existing nature conservation areas cover the sea depth of $20 \mathrm{~m}$ or less. Of 40 habitat classification units identified by BALANCE project 25 have their majority in the depth zone of $20 \mathrm{~m}$ or less. Same depth zone has $87 \%$ of all Baltic Sea photic zone. Table 2 shows quantitative characterization of distribution of benthic habitats and existing nature protection areas in relation to the depth zone potentially affected by offshore wind energy development. 
Table 2: Distribution of benthic marine habitats (defined by EU BALANCE project as marine landscapes) and other features in the Baltic Sea area (excluding Kattegat).

\begin{tabular}{|c|c|c|c|}
\hline Feature/habitat* & Total area & $\begin{array}{l}\text { Depth } 20 \mathrm{~m} \text { or less, } \\
\mathrm{km}^{2}\end{array}$ & $\begin{array}{l}\text { Depth } 20 \mathrm{~m} \text { or less, } \\
\text { percent from total }\end{array}$ \\
\hline 111 & 176.4 & 162.1 & 91.9 \\
\hline 112 & 2782.1 & 2507.8 & 90.1 \\
\hline 113 & 167.2 & 157.7 & 94.3 \\
\hline 114 & 1.8 & 1.8 & 99.7 \\
\hline 121 & 104.0 & 61.7 & 59.4 \\
\hline 122 & 4121.1 & 2053.8 & 49.8 \\
\hline 123 & 940.7 & 84.4 & 9.0 \\
\hline 124 & 2.3 & 2.2 & 97.9 \\
\hline 211 & 4269.1 & 4054.9 & 95.0 \\
\hline 212 & 6533.8 & 6312.6 & 96.6 \\
\hline 213 & 1034.2 & 1015.7 & 98.2 \\
\hline 214 & 524.0 & 484.7 & 92.5 \\
\hline 221 & 10365.9 & 4532.3 & 43.7 \\
\hline 222 & 25903.7 & 8235.4 & 31.8 \\
\hline 223 & 5501.4 & 860.4 & 31.8 \\
\hline 224 & 689.8 & 157.8 & 15.6 \\
\hline 311 & 2265.0 & 2216.4 & 22.9 \\
\hline 312 & 5449.0 & 5381.2 & 97.9 \\
\hline 313 & 3295.7 & 3263.1 & 98.8 \\
\hline 314 & 497.0 & 491.8 & 99.0 \\
\hline 321 & 5880.7 & 2810.8 & 47.8 \\
\hline 322 & 26585.5 & 7715.7 & 29.0 \\
\hline 323 & 24237.5 & 7370.0 & 30.4 \\
\hline 324 & 2809.9 & 1621.7 & 57.7 \\
\hline 411 & 405.3 & 380.2 & 93.8 \\
\hline 412 & 2612.3 & 2491.1 & 95.4 \\
\hline 413 & 103.5 & 101.9 & 98.4 \\
\hline 414 & 9.6 & 9.6 & 100.0 \\
\hline 421 & 4798.1 & 695.5 & 14.5 \\
\hline 422 & 47174.4 & 4851.0 & 10.3 \\
\hline 423 & 30560.3 & 199.6 & 0.7 \\
\hline 424 & 2906.2 & 93.71 & 3.2 \\
\hline 511 & 1200.0 & 1153.5 & 96.1 \\
\hline 512 & 4202.1 & 3873.3 & 92.2 \\
\hline 513 & 452.9 & 447.3 & 98.7 \\
\hline 514 & 36.4 & 23.0 & 63.1 \\
\hline 521 & 14312.0 & 1999.2 & 14.0 \\
\hline 522 & 47910.2 & 4860.2 & 10.1 \\
\hline 523 & 58723.0 & 423.5 & 0.7 \\
\hline 524 & 16088.0 & 117.2 & 0.7 \\
\hline Nature protection areas & 36585.9 & 27111.1 & 74.1 \\
\hline Non-photic seafloor & 306355.1 & 30291.2 & 9.9 \\
\hline Photic bottom seafloor & 62944.2 & 54880.2 & 87.2 \\
\hline
\end{tabular}

*Habitat names are coded according to the following key - in three digit code first digit represents bottom substrate: $1=$ bedrock, $2=$ hard bottom, $3=$ sand, $4=$ hard clay, $5=$ mud; second digit photic zone: $1=$ photic, $2=$ aphotic; third digit salinity: $1=0-5$ psu, $2=5-7.5$ psu, $3=7.5-11$ psu, $4=11-18$ psu, $5=18-30$ psu, $6=<30$ psu. 
Habitat distribution data is based on marine landscape maps produced by EU funded project BALANCE, the data on protected areas of the Baltic Sea originates from the HELCOM map portal [6]. The light availability data used in the analysis has been produced within the EUSeaMap project. Map layer used was downloaded from HELCOM map portal [6].

The result of analysis indicate potential conflict and threat from interest of development of wind parks and location of nature values as large proportion of unique and rare habitats are located in the same area where the potential interest for development of wind parks would be located (depth zone less than $20 \mathrm{~m} \mathrm{[7]).}$

\section{Environmental impact to the marine ecosystem}

Offshore wind farms, while in operation, cover a large area of the sea and thereby include considerable part of marine habitat. Generally, the impacts of wind farms to the marine ecosystem have been estimated to be positive on a global scale but negative on a local scale [8]. Some impacts are specific to the offshore wind parks, but there are also a number of impacts that differ significantly between the construction and operational phases (fig. 1).

One of the largest impacts on the marine environment originating from offshore wind parks so far documented is the so called "reef effect" [10],

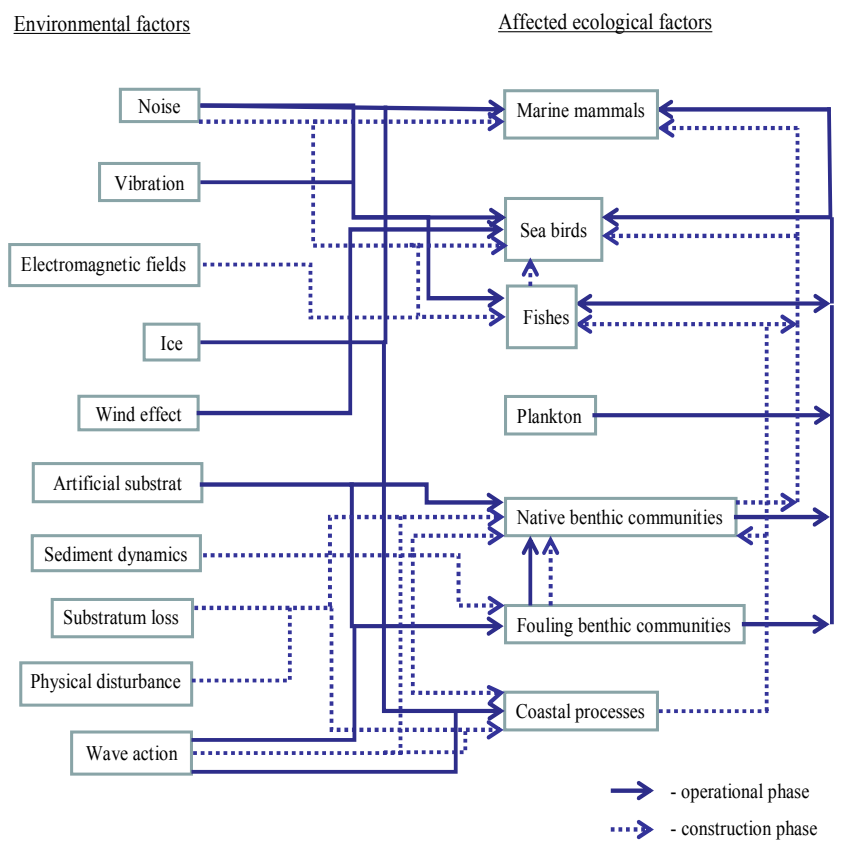

Figure 1: Diagram illustrating possible impact of different stressors related to the operation and construction of offshore wind park to different components of marine ecosystem [9]. 
primarily caused by solid manmade structures founded on the seafloor $[2,11]$. Offshore wind park turbines are functioning as artificial reefs, affecting local ecosystem [12]. Artificial structures may favour the settlement, reproduction, growth and change in biomass of native and fouling benthic species, which could influence the small and large scale processes in coastal and offshore systems [12].

Blue mussels (Mytilus trossulus) and barnacles (Amphibalanus improvisus) dominate hard bottom and also possible artificial substrate [9, 11-14] in the most part of the Baltic Sea. Both species are superior competitors in benthic communities due to a massive recruitment and rapid growth $[11,15,16]$. Introduction of hard substrate by construction of wind parks enables the colonisation of the aforementioned species which may significantly change the local dynamics of ecosystem. The phenomenon of artificial reefs is favourable for marine birds by improving feeding conditions and for fishes by providing better feeding conditions and shelter against predators [8, 9, 17, 18]. Artificial reefs can potentially be beneficial also for marine mammals [19]. Monopile as an effect of artificial reef attract species that would not have been wind park areas before [20].

It has been shown that among primary producers the artificial structures in the Baltic Sea are dominated by annual filamentous green algae in the sections close to sea surface [21]. The remaining part of the wind turbine is usually dominated by brown and red algae (Pilayella/Ectocarpus, some species of Ceramium family) $[21,22]$. They have adaption of poor light conditions in the cold and nutrient rich water [23]. So far relatively few macroalgal species have been identified to inhabit wind park installations, mainly because of poor light conditions [17]. It has been also noted that occurrence of green algae is rare in those habitats [22].

Occurrence of reef effect in connection with installation of new hard substrate has high importance for the soft bottom communities. The construction of wind parks adds hard substrate on soft bottom and it changes completely existing seabed habitats. Native benthic communities are partly or completely replaced by fouling benthic communities associated with hard bottom structures [9].

Study on possible effect of disturbance on hard bottom habitat by construction of gravitational foundations of offshore wind park was carried out in the Neugrund Bank, NE Baltic Sea. It was concluded that in certain depth intervals the amount of disturbed seafloor causes significant, long term changes in benthic communities. In shallower depths the disturbed communities recovered within one vegetation season while in deeper and intermediate depths the effect of disturbance was observed over several vegetation periods causing change in community structure and also favouring occurrence of new species previously not recorded in the native communities.

Physical disturbance, like installation of turbine and cable, affects sediment dynamics, causes removal of sediments (substratum loss) [17, 21-24], and influences currents and waves [18, 21]. These changes affect benthic communities, fishes, sea birds and marine mammals [18, 24, 26]. Habitat loss and change in hydrodynamic regime depends on the diameter, size and shape of 
turbine and the foundation type $[17,22]$. Higher turbine capacity requires larger monopiles [22], that consequently cause more extensive loss of substrate and changes in the water currents.

Installation of cables could cause electromagnetic fields and heat emissions, which influence marine organisms [22], especially fish. It may influence the behaviour and migration of the fish fauna $[17,22,27]$, because they use the Earth's magnetic fields for navigation. The cable could act as a barrier to the migration of fish [17, 27] and also have scaring effect [27]. Heat emission can change physicochemical conditions of sedimentary substrates leading to positive impact on reproduction of certain species, especially those adapted to warmer water [22]. Currently there are no studies reporting impacts of electric or magnetic fields on marine invertebrates [22].

Underwater noise and vibration have not been reported to affect marine invertebrates and attached fauna [22], but noise and vibration may have effects on fish and marine mammals. Pile driving and servicing vessels activities are the main problems in the wind park areas [28, 29]. Shallow areas are important calving and nursing areas for harbour porpoises and they are reported to partly or completely avoid the wind park areas [19, 21, 27-29]. Turbine installation and servicing boats make loud noise that may cause injuries and deafness $[8,19,27$, 28]. It has been observed that seals have returned to the construction sites after construction was completed.

Some offshore areas are rich in large bird species and these areas are breeding, roosting and feeding habitats. Offshore wind parks influence marine birds in several ways. Risk of collision is related to species, abundance and behaviour of birds and number of wind turbines [30]. Collision risk is higher at sea than on land, because turbines are taller and rotor blades are longer [31, 32]. Most collisions take place at night, especially on moonless night or in unfavourable weather condition like fog and rain [32]. Offshore wind farms are considered to be artificial barriers on migration routes [30, 32]. During the construction phase, short-term loss of breeding, feeding and roosting habitats may appear [31, 32].

Offshore wind parks increase collision risk for bats and also cause destruction of habitats, commuting corridors, roosts and feeding areas [33]. Bats forage over the sea in areas with an abundance of insects in the air and crustaceans in the surface water [34]. Installation of wind turbines will probably have negative impacts on bat populations.

In general it could be concluded that offshore wind farm has a potential to be a new habitat for marine biota and causes significant changes in the environment and habitat quality in closest vicinity and possibly a cumulative effect over large areas.

\section{Conclusions}

The Baltic Sea has a number of unique features and properties that should be taken into account while planning and executing large-scale technical installation projects including erection of offshore wind energy parks. Effects on the 
ecosystem can differ in the different parts of the Sea depending on several local features and large scale gradients. While most of the environmental effects could be treated as reversible and insignificant, low species diversity, specific physical features, such as ice conditions and extremely low water transparency, should be treated as additional risk factors having magnification effect for any possible impact. Addition of hard substrate to the soft bottom environment, so called "reef effect", has potentially very significant impact to local benthic habitat quality. Similar effect can be expected also for disturbance of hard substrate speed of recovery and degree of impact can differ in different parts of the Baltic Sea area and should be carefully considered in each separate case.

\section{Acknowledgement}

This study was carried out with financial support of the Estonian Science Target Financing Programme of Institutional Research Funding IUT02-20 of the Estonian Research Council.

\section{References}

[1] Breton, S.P. and Moe, G. Status, plans and technologies for offshore wind turbines in Europe and North America. Renewable Energy, 34, pp. 646654, 2009.

[2] Punt, M.J., Groeneveld, R.A., Ierland van E.C. and Stel, J.H. Spatial planning of offshore wind farms: A windfall to marine environmental protection? Ecological Economics, 69, pp. 93-103, 2009.

[3] Henderson, A.R., Morgan, C., Smith, B., Sørensen, H.C., Barthelmie, R.J., Boesmans, B. Offsore wind energy in Europe - a review of the state of the art. Wind Energy, 6, 35-52, 2003.

[4] Global Offshore Wind Farms Database, http://www.4coffshore.com /offshorewind/

[5] HELCOM. Checklist of Baltic Sea macrospecies. Baltic Sea Environment Proceedings No. 130, eds. T. Kontula and J. Haldin, Helsinki Commision: Helsinki, pp. 5-202, 2012.

[6] HELCOM, http://maps.helcom.fi/website/mapservice/index.html

[7] Wikes, J. The European offshore wind industry - key trends and statistics 2009. The European Wind Energy Association, pp. 3-14, 2010.

[8] Snyder, B. and Kaiser, M. Ecological and economic cost-benefit analysis of offshore wind energy. Renewable Energy, 34, pp. 1567-1578, 2009.

[9] Hiscock, K., Tyler-Walters, H. and Jones, H. High level environmental screening study for offshore wind farm developments - marine habitats and species project. The Department of Trade and Industry New and Renewable Energy Programme, nr. 30, ed. K. Hiscock, H. Tyler-Walters and H. Jones, pp. 10-11, 2002.

[10] Petersen, J.K. and Malm, T. Offshore windmill farms: threats to or possibilities for the marine environment. Ambio, 35, pp. 75-80, 2006. 
[11] Maar, M., Bolding, K., Petersen, J. K., Hansen, J.L.S. and Timmermann, K. Local effects of blue mussels around turbine foundations in an ecosystem model of Nysted off-shore wind farm, Denmark. Journal of Sea Research, 62, pp. 159-174, 2009.

[12] Wilhelmsson, D. and Malm, T. Fouling assemblages on offshore wind power plants and adjacent substrata. Estuarine, Coastal and Shelf Science, 79, pp. 459-466, 2008.

[13] Kautsky, N. Growth and size structure in a Baltic Mytilus edulis population. Marine Biology, 68, pp. 117-133, 1982.

[14] Westerbom, M., Kilpi. M. and Mustonene, O. Blue mussels, Mytilus edulis, at the edge of the range: population structure, growth and biomass along a salinity gradient in the north-eastern Baltic Sea. Marine Biology, 140, pp. 991-999, 2002.

[15] Dürr, S. and Wahl, M. Isolated and combined impacts of blue mussels (Mytilus edulis) and barnacles (Balanus improvisus) on structure and diversity of a fouling community. Journal of Experimental Marine Biology and Ecology, 306, pp. 181-195, 2004.

[16] Gibson, R., Hextall, B. and Roger, A. Photographic guide to the sea and shore life of Britain and North-West Europe. Oxford University Press: Oxford, 2001.

[17] Leonhard, S., Birklund, O. and Birklund, J. Change in diversity and higher Biomass (Chapter 4). In Danish offshore wind - key environmental issues, ed. J. Kjær, J.K. Larsen, C. Boesen, H.H. Corlin, S. Andersen, S. Nielsen, A.G. Ragborg and K.M. Christensen, DONG Energy, Vattenfall, The Danish Energy Authority and The Danish Forest and Nature Agency: Copenhagen, pp. 44-63, 2006.

[18] Roycroft, D., Kelly, T.C. and Lewis, L.J. Birds, seals and the suspension culture of mussels in Bantry Bay, a non-seaduck area in Southwest Ireland. Estuarine, Coastal and Shelf Science, 61, pp. 703-712, 2004.

[19] Teilmann, J., Tougaard, J., Carsetensen, J. and Dietz, R. Seals and porpoises react differently (Chapter 6). In Danish offshore wind - key environmental issues, ed. J. Kjær, J.K. Larsen, C. Boesen, H.H. Corlin, S. Andersen, S. Nielsen, A.G. Ragborg and K.M. Christensen, DONG Energy, Vattenfall, The Danish Energy Authority and The Danish Forest and Nature Agency: Copenhagen, pp. 80-93, 2006.

[20] Wilhelmsson, D., Malm, T. and Öhman, C. The influence of offshore windpower on demersal fish. ICES Journal of Marine Science, 63, pp. 775784, 2006.

[21] Nielsen, S. Offshore wind farms and the environment - Danish Experinece from Horns Rev and Nysted. Danish Energy Authority, Kopenhaagen, pp. 24-27, 2006.

[22] Meißner, K., Sordyl, H. Literature review of offshore wind farms with regard to benthic communities and habitats (Part B). In Ecological research on offshore wind farms: International exchange of experiences. Literature review of the ecological impacts of offshore wind farms, ed. C. Zucco, Federal Agency for Nature Conservation: Germany, pp. 2-39, 2006. 
[23] Leviton, J.S. Marine Biology - function, biodiversity, ecology. Oxford University Press: Oxford, 2001.

[24] Barnes, R.S.K. and Mann, K.H. Fundamentals of aquatic ecology. Blackwell Scientific Publications: Oxford, 1993.

[25] Poiwilleit, M., Kleine, J. and Leuchs, H. Impacts of experimental dredged material disposal on a shallow, sublittoral macrofauna community in Meclenburg Bay (western Baltic Sea). Marine Pollution Bulletin., 52, pp. 386-396, 2006.

[26] Reijnders, P.J.M., Brasseur, S.M.J.M., Borchardt, T., Comphysen, K., Czeck, R., Gilles, A., Jensen, L.F., Leopold, M., Lucke, K., Ramdohr, S., Scheidat, M., Siebert, U. and Teilmann, J. Marine mammals. Wadden Sea Ecosystem No. 25, eds. H. Marencic and J. de Vlas, Common Wadden Sea Secretariat and Trilateral Monitoring and Assessment Groups: Germany, pp. 8-22, 2009.

[27] Keller, O., Lüdemann, K. and Kafemann, R. Literature review of offshore wind farms with regard to fish fauna (Part B). In Ecological research on offshore wind farms: International exchange of experiences. Literature review of the ecological impacts of offshore wind farms, ed. C. Zucco, Federal Agency for Nature Conservation: Germany, pp. 48-118, 2006.

[28] Brandt, M.J., Diederichs, A., Betke, K. and Nehls, G. Responses of harbour porpoises to pile driving at the Horns Rev II offshore wind farm in the Danish North Sea. Marine Ecology Progress Series, 421, pp. 205-216, 2011.

[29] Carstensen, J., Henriksen, O.D. and Teilmann, J. Impacts of offshore wind farm construction on harbour porpoises: acoustic monitoring of echolocation activity using porpoise detectors (T-PODs). Marine Ecology Progress Series, 321, pp. 295-308, 2006.

[30] Hüppop, O., Dierschke, J., Exo, K.M., Fredrich, E. and Hill, R. Bird migration studies and potential collision risk with offshore wind turbines. Ibis, 148, 90-109, 2006.

[31] Derwitt, A.L. and Langston, R.H.W. Assessing the impacts of wind farms on birds. Ibis, 148, pp. 29-42, 2006.

[32] Exo, K.M., Hüppop, O. and Garthe, S. Birds and offshore wind farms: a hot topic in marine ecology. Wader Study Group Bull, 100, pp. 50-53, 2003.

[33] Rodriques, L., Bach, L., Biraschi, L., Dubourg-Savage, M.J., Goodwin, J., Harbusch, C., Hutson, T., Ivanova, T., Lutsar, L. and Parsons, K. Wind turbines and bats: guidelines for the planning process and impact assessments. Doc.EUROBATS.MoP5.12.Rev.3.Annex1, pp. 1-19, 2006.

[34] Ahlén, I., Baagøe, H.J. and Bach, L. Behavior of Scandinavian bats during migration and foraging at sea. Journal of Mammalogy, 90, pp. 1318-1323, 2009. 